\title{
The Third Way of Seed Governance: The Potential of the Seed Commoning in Japan
}

\author{
Norie Tamura
}

\begin{abstract}
As both material entities and "packages" of genetic information, seeds are a common-a co-managed natural resource-in communities and regions all over the world. In this analysis of Japan's national potential for a commons approach to seed sovereignty, Norie Tamura looks through the lens of institutional change. In 2017, the revocation of the Main Crop Seeds Act, a law upholding the state-run seed system, triggered a major backlash in Japanese civil society. Many in the movement called for a revival of state control without fully recognizing the part it plays, for instance, in agricultural industrialization. Yet simultaneously, a range of seed commons exist in Japan at the village and prefectural level, as well as through the network maintained by the Japan Organic Agriculture Organization. For seed commoning to spread and consolidate in Japan, Tamura asserts a need for reintegrating the producer-user divide and fostering open communication between seed and civil sectors.
\end{abstract}

N. Tamura $(\varangle)$

Research Institute for Humanity and Nature, Kyoto, Japan e-mail: ntamura@chikyu.ac.jp

(C) The Author(s) 2022

Y. Nishikawa and M. Pimbert (eds.), Seeds for Diversity and Inclusion, https://doi.org/10.1007/978-3-030-89405-4_12 
Keywords Commoning - Community-based seed management · Formal seed system $\cdot$ Japan $\cdot$ Seed commons

\subsection{INTRODUCTION}

One of the most fundamental aspects of farmers' sovereignty is the freedom to choose which varieties to plant. Farmers determine this based on a comprehensive consideration of farm conditions, local climate and ecosystem, food culture, socioeconomic factors and their own cultivation techniques. However, sovereignty cannot exist without guaranteed access to seeds.

In our globalized era, when multinational corporations are taking control of the world's agricultural supplies, the global peasant movement has repeatedly probed the question of who owns seeds. That concern is in fact part of a larger proposition: who owns nature. The study of the commons, in which researchers continue to explore this question, has also provided an analytical lens on seed sovereignty.

Commons are generally recognized as communally used and managed natural resources. In a 1968 article in the journal Science, the US ecologist Garett Hardin first proposed "the tragedy of the commons", arguing that effective resource management can only be provided by the state or through markets, as communal resource management inevitably leads to resource depletion. Hardin's concept has had a great deal of traction. However, successful cases of co-management have been reported from all over the world (Berkes et al., 1989; Feeny et al., 1990). Based on those examples, Elinor Ostrom (1990) identified a set of design principles for the long-term viability of commons.

Ostrom and other scholars in this arena have framed a commons as a "third way" of managing resources that can provide more flexible and efficient governance than states or markets. In the twenty-first century, the field of commons studies has been expanded to non-material resources such as knowledge, information and culture (Bollier, 2014). As neoliberal globalization progresses, multinational corporations attempt to privatize all kinds of information with intellectual property frameworks. We are in the "second enclosure movement" (Boyle, 2003; Evans, 2005). The notion of a new commons has become ever more important. 
The multifaceted nature of seeds means that they are treated as commons in two ways: as a material resource, and as a source of genetic information (Sievers-Glotzbach \& Christinck, 2020). Seeds are a tangible common-pool resource, and community-based collective management provides flexible conservation, provision and redistribution of them on the ground (Balázs \& Aistara, 2018; Coomes et al., 2015; Mazé et al., 2020; Rattunde et al., 2020). On the other hand, seeds are also "packages" of plant genetic information and as such a common property of humanity. There are attempts to create a new seed commons based on the framework of other information commons (Kloppenburg, 2014; Kotschi \& Horneburg, 2018; Moeller \& Pedersen, 2018), the Open Source Seed Initiative in the United States being a prime exemplar (Kloppenburg, 2014).

Most discussions around seed sovereignty so far have implicitly assumed a configuration in which small farmers confront large agribusiness corporations. However, seed commons is the third way of governance, involving neither state nor market. If this is the case, will the change in state management also stimulate the notion of seed commons? In this chapter, I examine this question by looking at Japan's institutional changes in 2017 as an example.

\subsection{JAPAN's Formal SEED System AND Its Turbulent History}

The formal seed system in Japan has two strands. One is the registration system for varieties under the Plant Variety Protection and Seed Act (PVPSA), which in principle protects all new plant varieties. The PVPSA is the national law under the International Union for the Protection of New Varieties of Plants (UPOV) Convention, and is part of the international plant variety protection regime. Secondly, there is seed provisioning, further divided into two categories: major agricultural crops including rice, wheat, barley and soybeans, and other plant varietiesmainly vegetables and flowers. For the former, the government controls seed supply based on the Main Crop Seeds Act (MCSA). Hereafter, I use the term "public seed system" to refer to this form of management of major agricultural crop seeds.

The MCSA was enacted in 1952 to promote and produce superior varieties of major agricultural crops in response to post-war food shortages. Under the control and budgetary measures of the national government, 
prefectures had the primary role of supplying seeds. Their tasks included selecting varieties to promote production in their areas, planning the production of the seeds, examining the quality of the seeds produced and controlling their distribution (Hisano, 2017).

The key staples (rice, wheat, barley and soybeans, as indicated above) have historically been bred by exemplary farmers (tokunouka in Japanese) in various parts of Japan. However, since the rediscovery of Mendel's laws in 1900, modern breeding techniques have been mainstreamed, and public institutions have emerged as the main players in breeding (Fujimaki, 2013; Ishizumi, 1968). Particularly after the Second World War, in response to a national demand for increased food production, government-led breeding organizations took the initiative on the development of varieties suitable for various regions throughout the country (Fujimaki, 2013).

In the 1980s, as biotechnology advanced, the private sector gradually grew in capacity (Kashihara et al., 2013). In response, the MCSA was amended in 1986, and the designation of varieties to be recommended for cultivation was extended to privately bred ones. However, those bred by public institutions were still favoured as recommended varieties, making it difficult for private companies to enter the seed market (Hisano, 1999; Kashihara et al., 2013). The MCSA came to be seen as an obstacle to the competitiveness of Japanese agriculture by hindering motivation in the private sector to develop major crop varieties. Therefore, it was revoked in 2017, when Japan decided to join the Trans-Pacific Partnership Agreement.

However, this sudden decision caused a huge backlash in civil society and the MCSA rapidly became a matter of public concern (Hisano, 2017). Figure 12.1 shows the number of newspaper articles on the MCSA, based on the database of The Asabi Shimbun, one of Japan's major newspapers. In the period from August 1984 to October 2020, a total of 70 articles reporting on the MCSA emerged, 85\% of which were published in 2017 or later. It is clear that the decision to revoke the act has rapidly boosted interest in it, and in the public seed system more generally.

Growing social interest in the MCSA was driven by the public nature of major crop seed supply. Therefore, many of the articles on the act discuss the pros and cons of liberalizing supply. In addition, there were many references to the MCSA in election-related coverage, as since 2017 a number of candidates have pledged to reintroduce it as an issue in national or local elections. Similarly, there were many articles on a local 


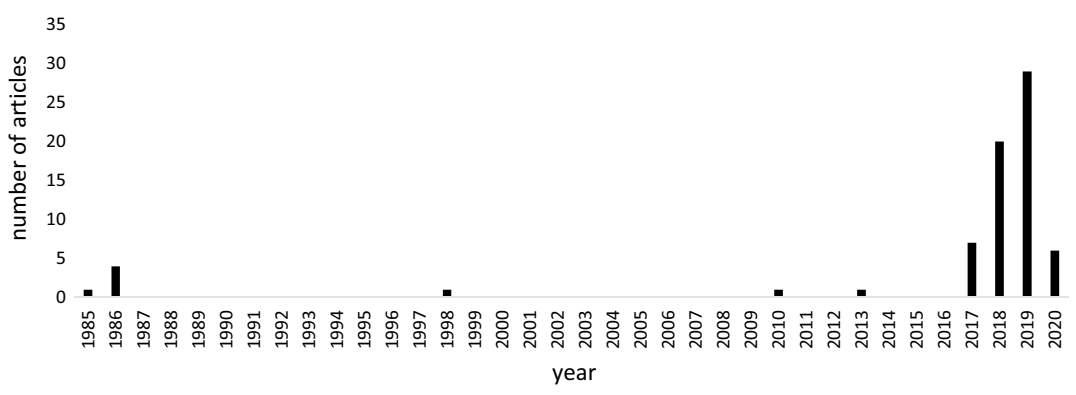

Fig. 12.1 Trends in the number of newspaper articles on the Main Crop Seeds Act

phenomenon emerging after the decision to revoke: to maintain the seed production and supply system, a number of prefectures proactively decided to enact ordinances to replace the MCSA. Civic groups have also gradually set their sights on both reviving the national law and enacting local ordinances. As of October 2020, 22 provinces and prefectures across the country have enacted ordinances that complement the MCSA.

\subsection{Critical Perspectives on the Public SeEd System for Major Crops}

The civic movement regarded the abolition of the MCSA as the dismantling of the public seed system, framing it as a surrender of the public to the private sector by the state (Inyaku \& GRAIN, 2020). Members of the movement were concerned that the move would enable an invasion by multinational agribusiness interests. Yet in looking for a means of countering the potential crisis, the movement did not call for seed commons, but rather for a revival of state control. In April 2018, Save Seeds Japan, a leading civic group, released a statement of protest against the repeal of the MCSA. It called for twofold action by the state: to immediately put "legal and budgetary measures" in place "to maintain and develop national and prefectural agricultural experiment stations", and to strengthen the "administrative measures and ordinances of local governments" (Save Seeds Japan, 2018). In my view, this framing of the issues stems from two misunderstandings on the part of the public. 
First, there has been insufficient critical examination of public seed systems in Japan. Colin Anderson et al. (2019) propose six critical domains for agricultural transformation: access to natural ecosystems, knowledge and culture, systems of exchange, networks, discourse, and gender and equity. And in fact, the public seed system's evolution in Japan, backed by a series of rice production stabilization policies, had triggered disruptions in these domains.

As mentioned above, public seed systems for major crops were introduced in response to post-war food shortages. Therefore, public institutions initially focused on developing high-yield varieties and technologies. Consequently, rice production had dramatically increased by the 1960s, and self-sufficiency in rice was achieved by 1965. In the 1970s, however, a rice surplus developed, and the government began to reduce production. On the consumption side, consumers' dietary habits and values have become more diversified along with rapid economic growth, and this has made taste and quality central to the value of rice. The rice surplus has also pushed consumption to shape production trends (Nakagahra et al., 1997).

These developments triggered widespread planting of brand-name varieties throughout the country (Kobayashi et al., 2018). Crop diversity was seriously diminished as a result. Rice varieties numbered about 4000 in the late nineteenth century; as of 2005 , that number has shrunk to just 88 varieties grown on cropland measuring 500 hectares or more (other varieties are grown on a smaller scale) (Ministry of the Environment, 2011). Prefectural agricultural research institutes began to focus on developing commercially unique varieties, and competition among production areas became more intense (Imabayashi \& Yoshida, 1990; Saito, 1990).

To produce quality rice, farmers were instructed to increase the rate of seed renewal. The development of mechanization has separated the seedling stage from the overall production process and barred many farmers from gaining the skills and knowledge involved in seed collection and seedling cultivation. The cost of machine installation also puts pressure on farmers' incomes. Thus, the public seed system has come to function as a part of the modern industrial farming system and has accelerated the commercialization of rice. In this process, traditional agroecological practices have been suppressed and farmers' sovereignty has been weakened. Progressive organic farmers and experienced extension officers have also pointed out these structural dependencies (Hayashi, 1985; Morita, 1994). 
Another misconception is that the protest movement has too naive a faith in the state. As James Quilligan (2013) has pointed out, in modern times the word "public" in effect means government, and government is vulnerable to lobbying and other forms of pressure-as he puts it, "captured by elite interests who regularly impede the people's political rights and capacity to control their common goods". Hence, the simple revival of the public seed system will not lead to agroecological transformation. Citizens need to turn their focus to seed commons.

\subsection{Seed Commons Practices Outside the Public Seed System}

In the public seed system based on the MCSA, the designation of a variety as desirable has a significant impact on the provisioning of seeds. Prefectural governments take the lead in discussions on designation, and varieties developed by public organizations, both national and prefectural, tend to be given priority. Varieties that have not been designated by the prefecture are difficult to cultivate practically due to inadequate supportive measures, such as difficulties in purchasing seeds and lack of agricultural guidance (Hisano, 1999). And the national government controls the entire system through budgetary measures.

Stefanie Sievers-Glotzbach et al. (2020) define four core criteria for seed commons: collective responsibility, protection from private enclosure, collective and polycentric management, and the sharing of formal and practical knowledge. The public seed system, due to its control by the national and prefectural governments, does not meet these criteria, especially in terms of collective responsibilities and management. Thus it can hardly be regarded as seed commons. For vegetable seeds outside the control of the government, of course, initiatives can be identified that meet these criteria.

The seed network managed by the Japan Organic Agriculture Association or JOAA (discussed in Chapter 7) is a typical example of seed commons. The association, a national organization of organic farmers, considers self-seeding to be an important technical element, and organizes seminars and open meetings to facilitate equal exchange of seeds and knowledge among members. Furthermore, it has established a system to save seeds provided by members and distribute them to those who wish to use them (JOAA, 2002). 
The Hiroshima Agricultural Gene Bank is operated by the local government. It not only collects and preserves genetic resources, but also distributes seeds free of charge to farmers within the prefecture. Farmers who take seeds are required to report the results after cultivation, and to collect and return more seeds than they borrowed. Prefectural extension experts provide technical guidance on cultivation and seed collection. Some farmers have revived traditional vegetables that were once cultivated from borrowed seeds, and are now producing them again. Under this scheme, farmers are not just users, but take part in the responsibility of managing the seed bank (Nishikawa, 2001; Nishikawa \& Winge, 2013).

In Nagano prefecture, the Seinaiji Akane turnip represents a novel variation on a traditional and local seed saving practice. The turnip is native to the region and has been traditionally served pickled. Around 2000, during a nationwide boom in traditional vegetables, the development of roads in the mountain village area of Seinaiji opened up business opportunities for tourism. The village government and local farmers group decided to commercialize traditional pickles as a specialty product. To do this, they had to standardize the native turnip. Traditionally, however, the vegetable has been maintained in multiple lineages, and traits have varied; and selection of fixed varieties had been attempted before but had not been successful.

The local community therefore collaborated with nearby Shinshu University to develop Fl varieties based on local strains. The developed varieties were jointly registered under the name of the university and the village. Seed production and distribution plans are determined by local farmers' groups. Many farmers in them grow the Fl seeds for commercial ends, as well as the indigenous varieties for their own use (Nemoto, 2012). In Seinaiji village, the community proactively engaged in the development of Fl varieties for the purpose of promoting local agriculture. The Fl varieties bred from local genetic resources can be seen as communally owned new varieties. I see this case as an elaboration of local seed commons practice. The development and registration of Fl varieties based on native varieties can happen not solely as a corporate, private act of enclosure; it can, alternatively, become an endeavour of local commons.

In the case of the Seinaiji Akane turnip, we can also see a local seed commons that has skillfully utilized the plant variety protection scheme based on the PVPSA. However, in 2020, under the influence of the civic seed movement, comments that protested strengthening the protection 
of breeders' rights through the revision of the PVPSA temporarily went viral on some social networking sites (see Box 12.1).

\section{Box 12.1: A Strategic Approach to Constructive Arguments for Seed Commons}

In April 2020, the Japanese actress posted on Twitter that Japanese farmers will be in trouble if the PVPSA is revised to ban self-seeding (Miyahara \& Tokubo, 2020). It was the first instance of a celebrity taking up the issue of seeds on social media.

Her post, which warned against the commercialization of seeds, went viral, but her statement was controversial. Her opinion was largely based on the notion of confrontation between big business and small farmers; but the revision in question aimed to protect breeders' rights, and small farmers who grow new varieties can benefit from it. There was an immediate, mixed reaction to her post.

This is an interesting example of pitfalls in the discourse on seeds. Discussion must be open to the public, but public learning on seeds is equally important. There should be a place for repeated discussion and learning, as the scholar Kazuko Tsurumi described: a non-confrontational integrative approach for protesting against governmental and/or corporate power (see also Box 3.1), not just a passing burst of protest.

Reference: Miyahara K., \& Tokubo I. (2020, May 21). LDP lawmaker suggests divisive bill to revise Japan plant protection law will be deferred. Mainichi Daily News. https://mainichi.jp/english/articles/20200521/ $\mathrm{p} 2 \mathrm{a} / 00 \mathrm{~m} / 0 \mathrm{fp} / 021000 \mathrm{c}$.

\subsection{Envisioning a Future of Seed "Commoning”}

That private enclosure is a risk now that the MCSA is revoked is not an unrealistic concern; it may well occur. However, the needed countermeasure is the establishment of seed commons, not a reliance on the conventional public seed system. Seeds as a commons is not an idealist's fantasy. As mentioned in this and other chapters in this book, several different patterns of time-tested seed commons exist throughout Japan.

Recently, a turn to the commons as a social act rather than an analytical tool in academia has been gaining attention (Bollier \& Helfrich, 2013; Bollier \& Helfrich, 2015; De Angelis, 2019; Euler, 2018). The verbal form of commoning is used in this context to mean regarding certain 
goods or services actively as commons, and to manage them in a democratic, care-based manner (care here signifying daily action "performed by human beings for their welfare and for the welfare for their community" [D'Alisa et al., 2014]). With seed commoning, the care of seeds is not separated from farmers' everyday lifestyle; it is instead embedded within their life and culture, as are attendant skills and knowledge. Eventually, commoning is expected to provide the foundation for a new socioeconomic system aimed at fostering a sustainable future (Vivero-Pol et al., 2018). Commoning-based socioeconomic structures could emerge from integrating the division between producers and consumers (Varvarousis \& Kallis, 2017).

Examples of seed commons in Japan also show that seed producers can be seed users, or that the two groups can be very closely linked. For major crop seeds, reintegrating the division between producers and users may be a starting point for seed commoning. Furthermore, participation is necessary-not only among citizens but also various actors in the seed sector. The civil sector should not only involve in international debates but should also learn about actual practices and struggles on the ground. And the seed sector should be open to civil society. Open communication and mutual understanding between the civil and seed sectors will form a basis for seed commoning in Japan as well as other countries.

\section{REFERENCES}

Anderson, C. R., Janneke, B., Chappell, M. J., Kiss, C., \& Pimbert, M. P. (2019). From transition to domains of transformation: Getting to sustainable and just food systems through agroecology. Sustainability, 11(19), 5272. https://doi. org $/ 10.3390 /$ sul11 195272

Balázs, B., \& Aistara, G. (2018). The emergence, dynamics and agency of social innovation in seed exchange networks. The International Journal of Sociology of Agriculture and Food, 24(3). https://doi.org/10.48416/ijsaf.v24i3.9

Berkes, F., Feeny, D., McCay, B. J., \& Acheson, J. M. (1989). The benefits of the commons. Nature, 340(6229), 91-93. https://doi.org/10.1038/340 $091 \mathrm{a} 0$

Bollier, D. (2014). Think like a commoner: A short introduction to the life of the commons. New Society Publishers.

Bollier, D., \& Helfrich, S. (Eds.). (2013). The wealth of the commons: A world beyond market and state. Levellers Press.

Bollier, D., \& Helfrich, S. (2015). Patterns of commoning. Off the Common Books/Levellers Press. 
Boyle, J. (2003). The second enclosure movement and the construction of the public domain. Law and Contemporary Problems, 33-74. Retrieved February 19, 2021, from https://scholarship.law.duke.edu/lcp/vol66/issl/2/

Coomes, O. T., McGuire, S. J., Garine, E., Caillon, S., McKey, D., Demeulenaere, E., Jarvis, D., Aistara, G., Barnaud, A., Clouvel, P., Emperaire, L., Louafi, S., Martin, P., Massol, F., Pautasso, M., Violon, C., \& Wencélius, J. (2015). Farmer seed networks make a limited contribution to agriculture? Four common misconceptions. Food Policy, 56, 41-50. https://doi.org/10. 1016/j.foodpol.2015.07.008

D'Alisa, G., Deriu, M., \& Demaria, F. (2014). 11. Care. In G. D'Alisa, F. Demaria, \& G. Kallis (Eds.), Degrowth: A vocabulary for a new era. Routledge.

De Angelis, M. (2019). Commons. In A. Kothari, A. Salleh, A. Esobar, F. Demaria, \& A. Acosta (Eds.), Pluriverse: A post-development dictionary. New Delhi: Tulika Books.

Euler, J. (2018). Conceptualizing the commons: Moving beyond the goodsbased definition by introducing the social practices of commoning as vital determinant. Ecological Economics, 143, 10-16. https://doi.org/10.1016/j. ecolecon.2017.06.020

Evans, P. (2005). The new commons vs. the second enclosure movement: Comments on an emerging agenda for development research. Studies in Comparative International Development, 40(2), 85-94. https://doi.org/10. $1007 / \mathrm{BF} 02686295$

Feeny, D., Berkes, F., McCay, B. J., \& Acheson, J. M. (1990). The tragedy of the commons: Twenty-two years later. Human Ecology, 18(1), 1-19. https:// doi.org/10.1007/BF00889070

Fujimaki, H. (2013). Nihon no ine ikusyu no kiseki to yukue: topics de tsuzuru ine hinsyu kairyo [Trajectory and future of rice breeding in Japan: Rice breeding in topics]. Record of the lecture at the Japan Agricultural Research Institute.

Hardin, G. (1968). The tragedy of the commons. Science, 162(3859), 12431248. https://doi.org/10.1126/science.162.3859.1243

Hayashi, N. (1985, February). Kome no hinshu: Hoshii tanemomi ga naze nyuushu dekinai? [Rice varieties: Why can't I get the rice fir I want?]. Gendai Nogyo, 248-252.

Hisano, S. (1999). Shuyou nousakumotsu shusi seidoka no kome shushi shijo to agribusiness no jigyou tenkai [The Japanese rice seed market under the 1986 Main Crop Seed Law and agribusiness strategies]. The Review of the Society of Agricultural Economics, 55, 73-85. http://hdl.handle.net/2115/11180

Hisano, S. (2017). Shuyou nousakumotsu shusihou haishi no keii to mondaiten -kouteki syusi jigyou no yakuwari wo aratamete kangaeru- [The process and problems with the abolishment of the Main Crops Seed Law of Japan: A need to revisit the role of public seed programme]. Kyoto University. http:// www.econ.kyoto-u.ac.jp/dp/papers/j-17-001.pdf 
Imabayashi, S., \& Yoshida, T. (1990). Fukuokakenn ni okeru suitou ikushu no torikumi to kongo no houkousei [Rice breeding in Fukuoka Prefecture]. Journal of Agricultural Science, 45(6), 256-258.

Inyaku, T., \& GRAIN. (2020). Trade deals handing Japanese seeds to multinational corporations. Retrieved July 1, 2021, from https://grain.org/en/art icle/6532-trade-deals-handing-japanese-seeds-to-multinational-corporations

Ishizumi, K. (1968). Wagakuni ni okeru suitou ikushu sosiki no utsurikawari to sono seika [Changes in the organization of rice breeding in Japan and their results]. Journal of Rural Problems, 4(1), 1-8. https://doi.org/10.7310/arf e 1965.4 .1

JOAA. (2002). Shubyou network kiyaku [Seed network rules]. Retrieved July 1, 2021, from https://www.1971joaa.org/

Kashihara, M., Kubo, T., Komura, T., \& Komari, T. (2013). Minkan kigyou ni yoru ineikusyu heno tyousen to kongo no kadai [Rice breeding programs of private companies in Japan and future challenges]. Breeding Research, 15(4), 173-183. https://doi.org/10.1270/jsbbr.15.173

Kloppenburg, J. (2014). Re-purposing the master's tools: The open source seed initiative and the struggle for seed sovereignty. The Journal of Peasant Studies, 41(6), 1225-1246. https://doi.org/10.1080/03066150.2013.875897

Kotschi, J., \& Horneburg, B. (2018). The Open Source Seed Licence: A novel approach to safeguarding access to plant germplasm. PLOS Biology, 16(10). https://doi.org/e3000023-10.1371/journal.pbio.3000023

Kobayashi, A., Hori, K., Yamamoto, T., \& Yano, M. (2018). Koshihikari: A premium short-grain rice cultivar-Its expansion and breeding in Japan. Rice, 11(1), 15. https://doi.org/10.1186/s12284-018-0207-4

Mazé, A., Domenech, A. C., \& Goldringer, I. (2020). Commoning the seeds: Alternative models of collective action and open innovation within French peasant seed groups for recreating local knowledge commons. Agriculture and Human Values, 38, 541-559. https://doi.org/10.1007/s10460-020$10172-\mathrm{z}$

Ministry of the Environment. (2011). Annual report on the environment, the sound material-cycle society and biodiversity in Japan. Retrieved July 1, 2021, from https://www.env.go.jp/en/wpaper/2011/index.html

Moeller, N. I., \& Pedersen, M. (2018). Open source seed networking: Towards a global community of seed commons: A progress report. HIVOS.

Morita, S. (1994). Shuyounousakumotsu shushibou haishi heno kougi to nibon no shushi wo mamoru undou sengen [Protest against the abolition of the major crops seed law and declaration of movement to protect seeds in Japan]. Nosan Gyoson Bunka Kyokai.

Nakagahra, M., Okuno, K., \& Vaughan, D. (1997). Rice genetic resources: History, conservation, investigative characterization and use in Japan. In 
T. Sasaki \& G. Moore (Eds.), Oryza: From molecule to plant. Springer Netherlands.

Nemoto, K. (2012). Conservation and management of plant genetic resources in Nagano Prefecture, Japan. Journal of the Faculty of Agriculture. Shinshu University, 48(1-2), 85-92. http://hdl.handle.net/10091/15721

Nishikawa, Y. (2001). Chihou hinshu no katsuyou niyoru gene bank to nouka no atarashii kankei: Hiroshimaken gene bank wo jirei toshite [New relations between gene bank and farmers in practical utilization of land-races: A case of Hiroshima Agricultural Gene Bank. Journal of Agricultural Development Studies, 12(1), 76-83. Retrieved (abstract only and full text is only in printed version) July 21, 202 1, from https://agris.fao.org/agris-search/search.do?rec ordID $=J P 2002000370$

Nishikawa, Y., \& Winge, T. (2013). The Hiroshima Agricultural Gene Bank: Re-introducing local varieties, maintaining traditional knowledge. In $\mathrm{R}$. Andersen \& T. Winge (Eds.), Realising farmers' rights to crop genetic resources. Routledge. https://doi.org/10.4324/9780203078907

Ostrom, E. (1990). Governing the commons: The evolution of institutions for collective action. Cambridge University Press.

Quilligan, J. B. (2013). Why distinguish common goods from public goods? The wealth of the commons. In D. Bollier \& S. Helfrich (Eds.), The wealth of the commons: A world beyond market and state. Amherst, MA: Levellers Press.

Rattunde, F., Weltzien, E. Sidibé, M., Diallo, A., Diallo, B., vom Brocke, K., ... Christinck, A. (2020). Transforming a traditional commons-based seed system through collaborative networks of farmer seed-cooperatives and public breeding programs: The case of sorghum in Mali. Agriculture and Human Values, 38(1), 561-578. https://doi.org/10.1007/s10460-020-10170-1

Saito, S. (1990). Meigaramai "Akita Komachi" no ikusei to ryuutsuutaiou [Breeding and marketing of brand rice 'Akitakomachi']. Journal of Agricultural Science, 45(1), 14-18.

Save Seeds Japan. (2018). Shuyounousakumotsu shushihou haishi heno kougi to nihon no shushi wo mamoru undou sengen [Protest against the abolition of the major crops seed law and declaration of movement to protect seeds in Japan]. Retrieved July 26, 2021, from https://www.taneomamorukai.com/ seimei

Sievers-Glotzbach, S., \& Christinck, A. (2020). Introduction to the symposium: Seed as a commons-Exploring innovative concepts and practices of governing seed and varieties. Agriculture and Human Values, 38, 499-507. https://doi.org/10.1007/s10460-020-10166-x

Sievers-Glotzbach, S., Tschersich, J., Gmeiner, N., Kliem, L., \& Ficiciyan, A. (2020). Diverse Seeds-Shared Practices: Conceptualizing Seed Commons. International Journal of the Commons, 14(1), 418-438. https://doi.org/10. $5334 /$ ijc. 1043 
Varvarousis, A., \& Kallis, G. (2017). Commoning against the crisis. In M. Castells (Ed.), Another economy is possible: Culture and economy in a time of crisis. Polity.

Vivero-Pol, J. L., Ferrando, T., De Schutter, O., \& Mattei, U. (Eds.). (2018). Routledge handbook of food as a commons (1st ed.). Routledge.

Open Access This chapter is licensed under the terms of the Creative Commons Attribution 4.0 International License (http://creativecommons.org/licenses/ by $/ 4.0 /$ ), which permits use, sharing, adaptation, distribution and reproduction in any medium or format, as long as you give appropriate credit to the original author(s) and the source, provide a link to the Creative Commons license and indicate if changes were made.

The images or other third party material in this chapter are included in the chapter's Creative Commons license, unless indicated otherwise in a credit line to the material. If material is not included in the chapter's Creative Commons license and your intended use is not permitted by statutory regulation or exceeds the permitted use, you will need to obtain permission directly from the copyright holder.

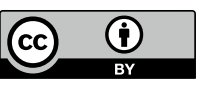

